\title{
Kønnets \\ anatomiske
metaforer anatomiske
metaforer
}

Af Lilian Munk Rösing

Diskussionen af forboldet mellem anatomi og metafor setter fokus på anatomiens status $i$ psykoanalysen. Kan psykoanalysen blive feministisk ved at udkaste nogle anatomiske metaforer som er alternativer eller supplementer til "fallos"? 
en ren kulturel konstruktion, en materiel "effekt" af magten. Jeg hævder, at kroppen opstår i dialog mellem anatomien og fantasien. Kroppens former og funktioner melder sig for det lille barn dels som en materiel erfaring, dels som gåder og mysterier der bliver objekt for barnets fantasi og spekulationer. En fundamental materiel kropserfaring er erfaringen af kønsforskellen; en fundamental kropslig fantasi, er fantasien om kønsforskellens betydning; en fantasi der både henter næring af den reelle erfaring og kulturens forestillinger (fantasier) om kønnet. En fundamental gåde i barnets (og siden den voksnes) fantasi, er gåden om kønsforskellens betydning.

Jeg hævder (med kropsfænomenologien), at kroppen er en situation. Kroppen er et sted, hvorfra vi sanser verden og os selv. Kroppens potentielle og aktuelle former og funktioner, er med til at forme, den måde vi sanser verden på. Jeg hævder (mod kropsfænomenologien) at disse former og funktioner har kønsspecifikke træk. Jeg hævder endvidere, at kroppen er et metafor-reservoir. Det vil sige, at de metaforer, de billeder vi bruger for at forstå eller formidle ikke-kropslige erfaringer, i høj grad er hentet fra kroppen. "Det er hovedsagen”, “det væltede ud af ham”, “jeg var lige ved at gå ud af mit gode skin”, "han er alt for tilbageholdende", "jeg labbede det i mig”, “det var en øjenåbner”, “det var meget bevægende", "hun er så knibsk”, “det kræver virkelig nosser" osv.; i vores dagligsprog gør vi hele tiden kroppens former, funktioner og processer til billeder på det vi sanser, føler og tænker. Det betyde, at den anatomiske krop er med til at strukturere vores selv- og verdensoplevelse, men også at der i vores kulturelle koder, i vores sprog findes nedlagt et særligt kropsbillede. At kroppen har metaforisk status betyder således både at den giver materiale og struktur til de metaforer vi begriber verden og os selv igennem, og at den selv struktureres af metaforer hvis kropslige oprindelse er blevet glemt.

\section{ANATOMETAFORI}

Hvis man vil finde et begreb om en krop, der strukturerer vores selv- og verdensoplevelse og som er udstyret med kønsorganer, må man gå til psykoanalysen. For psykoanalysen betyder alting krop, og kroppen betyder altid noget andet end sig selv. Psykoanalysen vrimler som bekendt med anatomiske begreber, "fallos", "kastration", "det onde bryst", "penismisundelse", "analretinens", “oralfiksering" osv. Alle begreber der refererer til kropslige organer og processer. Disse begreber har status af anatomiske metaforer. Hvad vil det sige? Hvad er anatomi, og hvad er metafor?

Anatomi er skxbne, sagde Freud. Og det lyder jo lovlig deterministisk. En psykoanalytisk kønsfilosof der fuldstændig stilrent har videreført denne anatomiske determinisme, er Camille Paglia. I sin provokerende og voldsomt velskrevne bog Sexual Personae fastholder hun kvinden som naturens vegeterende, boblende (og skræmmende) urskød, mens manden er den falliske stræber der (med sine bygninger, sine opfindelser, sin naturbettvingende teknik) kæmper for at rejse sig af dette skød. "Mænd er anatomisk bestemte til at udkaste projekter", skriver hun, med ublu henvisning til mandens erektion og urinstråle. Mænds og kvinders forskellige måder at tisse på er for Paglia en nøgle til forståelse af deres forskellige karakterer (og dermed følgende roller i kulturen): den urinerende mand er som hanhunden en "graffiti artist", mens den urinerende kvinde som hunhunden er en "earth bound squatter". Hvis kvinderne havde styret verden, skriver hun, ville vi stadig bo i tørvehytter. Paglia er vel at mærke de urinerende hanhunde dybt taknemmelig; hun har absolut ingen romantisk drøm om at vende tilbage til den natur, der for hende er en sydende, boblende, xkel - og kvindelig - sump; hun sætter pris på sit skrivebord, sin pc, sit elektriske lys og al den civilisation, hun mener, vi kan takke manden og hans klare urinstråle for. Paglias klokkeklare anatomiske determinisme kompliceres dog 
af en af hendes egne anatomiske metaforer: et sted skriver hun om "nature's mad spermatic bubbles", naturens vanvittige og spermagtige bobler og făr hermed pludselig udledt ursumpen af den mandlige anatomi.

Selv om Freud bombastisk har hævdet, at anatomi er skæbne, er det et andet og mere kompliceret kropsbegreb, der træder i relief, når man for alvor går ind i hans psykoanalytiske teori. I sin fornemmelse for det komplekse forhold mellem krop og psyke, sin fornemmelse for hvordan kroppen kan tale i psykens sted (hysterikerens symptomer), og hvordan vores mentale og kulturelle billeder omvendt kan udtrykke kroppen (fallossymboler og deslige), viser Freud os en anatomi, der ikke determinerer vores mentale rum, men som hele tiden er med til at forme dette rum, samtidig med at den selv formes af det.

Det er en udbredt misforståelse, at psykoanalysen skulle betragte de kropslige frnomener som altings facit; som det alting kan føres tilbage til. I denne misforståede opfattelse skulle f.eks. en mands nærighed kunne "føres tilbage til" hans barndoms forstoppelse og hans angst til hans barndoms angst for at miste sin penis. Men sådan forholder det sig ikke. Snarere må man sige, at angsten kan finde en anatomisk metafor i kastrationsangsten, og nærigheden kan finde en anatomisk metafor $\mathrm{i}$ forstoppelsen

Hvad er en metafor? I den klassiske retoriks forståelse er metaforen kendetegnet ved et ligheds- og erstatningsforhold mellem to fænomener. Man producerer metaforer, når man benævner et fænomen med navnet på et andet fænomen, som ligner det. Når man benævner kvinden med navnet rose, sjælen med navnet sommerfugl osv. Erstatningsnavnet kaldes metaforens "billedled", mens det erstattede navn kaldes metaforens "sagled": rose er billedled, kvinde er sagled; sommerfugl er billedled, sjæl er sagled.

Hvad vil det da sige at f.eks. "kastration" er en metafor? Det vil sige at "kastration" er et konkret, kropsligt fænomen, der kan fungere som konkret "billedled" i forhold til et mere diffust og abstrakt sagled: oplevelsen af at miste noget, at ikke være perfekt osv. Men samtidig er kastration også et "sagled": I drømmens eller kulturens billeder vil man kunne opleve afhuggede fingre, nedhuggede træer osv. som "billedled", hvor kastrationen er "sagled".

Psykoanalysen betragter alt som metaforer for kroppen, men betragter samtidig kroppen som metafor for noget andet end sig selv. Metaforteoretisk er kroppen for psykoanalysen et sagled, der altid også vil være et billedled.

Lad os tage et eksempel. En kvinde plages af en følelse af at være utilstrækkelig i sin mandsdominerede karriereverden; at hun dybest set ikke har det talent, der skal til, og kun får den anerkendelse, hun får, fordi ingen endnu har opdaget hendes fundamentale mangel. Den psykoanalytiske diagnose turde være klar: en kvinde der bliver ved med at kredse om sin egen fundamentale mangel, om et eller andet der fra naturens hånd simpelt hen ikke er hende forundt, er en kvinde, der lider af penismisundelse. Men med "penismisundelsen" har kvindens problem ikke fundet sin løsning, blot sin anatomiske metafor. Kvindens følelse af utilstrækkelighed har hængt sig op på en kropslig erfaring: den anden har en penis, det har jeg ikke; der er noget, jeg fundamentalt mangler og aldrig vil kunne erhverve mig kunstigt. Den anatomiske metafor "penismisundelse" er en anskueliggørelse af denne følelse og kan hjælpe kvinden med at bearbejde den (det vil sige finde nye metaforer for den!). En kvinde der lider af penismisundelse, er en kvinde, der betragter den eksemplariske anden (den der har et andet køn) som den, der har noget, hun selv mangler. Det kan der være både personlige og kulturelle årsager til, men den anatomiske metafor giver kvinden mulighed for at xndre sin selvoplevelse ved at xndre sin kropsoplevelse; i stedet for hele tiden at opleve sig selv (negativt), som 

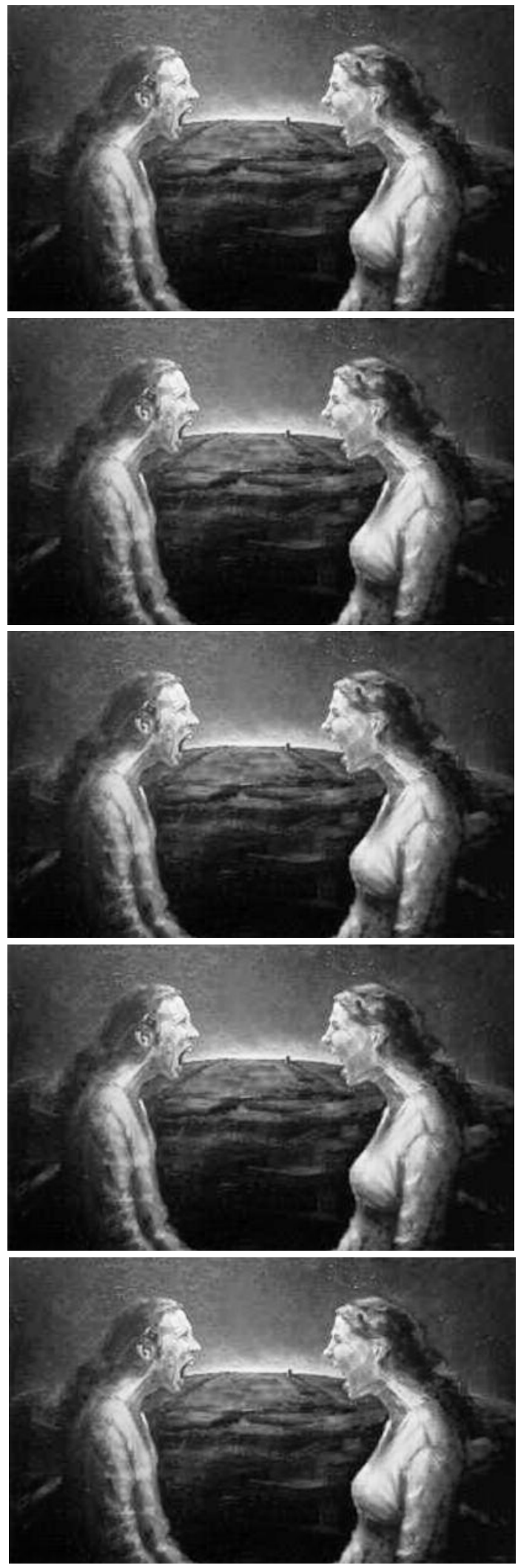

"den der ikke har (penis)", kan hun begynde at opleve sig selv positivt som, "den der har (vagina)"; i stedet for at opleve den anden som, "den der har (penis)" kan hun begynde at opleve den anden som, "den der heller ikke har (fallos)", det vil sige, den der er lige så ufuldkommen som hun selv.

For psykoanalysen er kroppen den primære betydningsbærer, ikke den endelige betydning. Det vil sige: vores voldsomme emotionelle erfaringer (angst, fryd, vrede osv.) indskriver sig fra første færd i kroppen, forstås i kroppens billeder. Kroppen er ikke svaret på alle gåder (vi har ikke løst nogen gåde ved at tolke en tunnel som en vagina), men selv en gåde. For det lille barn er kroppen og dens funktioner et mysterium, og barnets første spekulationer (som siden kan blive til forskerens videbegær) er spekulationer over kroppens mysterier.

\section{KROPPEN SOM TEGN}

Alting henviser til kroppen, og kroppen henviser altid til noget andet end sig selv. Man kan ikke se bort fra nogen af retningerne i denne gensidige henvisning. Ser man bort fra henvisningen til kroppen, bliver man konstruktivistisk reduktionist. Ser man bort fra henvisningerne til "noget andet", bliver man biologistisk reduktionist.

Lad os tage et klassisk eksempel: spædbarn ved moderbryst. Brystet har en betydning. Dels en betydning der går op i den biologiske funktion: brystet giver næring og tæt fysisk kontakt med moderen. Dels en betydning der overskrider denne biologiske: brystet er en del af moderens historie, som ikke mindst er en seksualitetshistorie: det har været objekt for begær og fantasier i moderens seksuelle liv. Dels betyder brystet så at sige "sig selv", sin egen biologiske funktion, dels betyder det "noget andet", idet det er blevet graveret med kulturens og seksualitetens koder.

Spørgsmålet er naturligvis, hvordan dette "andet", denne merbetydning ved brystet kommer ind i spædbarnets bevidsthed. Der 
findes dem, der (som Melanie Klein) mener, at barnet har en medfødt viden om forplantningsprocesserne, og at det således helt intuitivt kender til brystets andel i seksualiteten. Og så findes der andre, der (som Jean Laplanche) betoner, at det er moderens fantasier, der skaber denne merbetydning, også i barnet; at hele den "viden" moderen sidder inde med om brystets seksuelle historie, så at sige lægger sig om brystet som en gådefuld aura, der giver barnet en fornemmelse af, at der er noget "mere", noget "andet" ved dette bryst. I denne historie er allerede seksualiteten "noget andet” end biologi (jvf. Laplanche).

Lige så snart vi bevæger os ind i seksualiteten, bevæger vi os ind i en zone, hvor kroppen betyder andet og mere end sig selv. Den seksuelle krop er en tolket krop. “Tolkningen" er ikke at føre alting tilbage til seksualiteten; tolkningen er allerede en del af seksualiteten selv; den seksualiserede krop er den tolkede krop. Og spædbarnets krop bliver fra første færd seksualiseret/tolket.

Det vil sige, kroppen er fra første færd ikke bare tegnproducerende, men selv et tegn. Ikke den endelige betydning, men den primære betydningsbærer. Ikke altings sagled, men selv et billedled. Ikke det sted hvor al betydning ender, men det sted hvor al betydning begynder. Får man i psykoanalysen tolket sig "tilbage" til dette sted, er det først her, man kan begynde at tolke, det vil sige skabe nye metaforer. Bruge kroppen som materiale for nye metaforer.

\section{FALlOS SUPPLERET}

Psykoanalysens arkemetafor er "fallos". Hvis folk ikke ved andet om psykoanalyse, så ved de, at den går ud på at tolke enhver ret linie (søjle, fyrtårn, sværd) som en "fallos", selv om det er Freud selv, der har sagt, at "nogle gange er en cigar bare en cigar".

Når man tolker kulturskabte former som afspejlinger af den mandlige anatomi (det mandlige erigerede lem), kan det se ud, som om man gør anatomien til det endelige "sagled", til altings betydning. Men det psykoanalytiske begreb er jo netop "fallos" og ikke "penis"; det psykoanalytiske begreb er ikke penis, men et penissymbol, en metafor for penis. I selve begrebet ligger en adskillelse mellem (den symbolske) fallos og (den reelle) penis. Selv om "fallos" ikke kan forstås som det konkrete mandlige kønsorgan, kommer vi imidlertid ikke uden om, at det er en metafor, der er støbt over den mandlige anatomi. Spørgsmålet er, om man kan tænke sig nogle metaforer, der er støbt over den kvindelige anatomi - og om de kunne være med til at rokke ved det patriarkalske kønssystem, vi lever under.

Man må erkende, at vore fundamentale filosofiske begreber (også dem der implicit, på det ubevidste plan, strukturerer vores selv- og verdensopfattelse) er støbt over mandlig anatomi og mandlige fantasier om kvindelig anatomi. Men man må også erkende, at den mandlige anatomis ypperste tegn, "fallos", netop er et tegn, et symbol, en metafor. Og at man, når man har erkendt den som sådan, kan indse, at også noget så kvindeanatomisk som moderbrystet kan være en fallos. Både (i konkretiserende retning) fordi barnets første erfaring af anatomisk potens er erfaringen af moderbrystet, og (i abstraherende retning) fordi "fallos" betyder den fuldendte form, som også brystets afrundede kuppel kan opleves som. Altså: både fordi fallos er en metafor for moderbrystet (barnet erfarer sutteflasken eller den erigerede brystvorte før det erfarer den erigerede penis) og fordi brystet er en metafor for fallos (den senere xstetisering af brystet gør brystet til et udtryk for fallos som fuldendt form).

Ved at gøre "fallos" til arkemetaforen (eller "mestersignifianten", som Lacan ville sige), giver psykoanalysen den mandlige anatomis metafor en særlig privilegeret status, som afspejler den status, den mandlige anatomi har i den herskende (patriarkalske) samfundsorden. Det kan vi forstå på to måder: dels på den måde at vores kulturbæ- 
rende metaforer og begreber er metaforer for den mandlige anatomi, dels på den måde at de er metaforer fra den mandlige anatomi. I det ene tilfælde forstås det som om kulturen har haft travlt med at producere metaforer for den mandlige anatomi; i det andet tilfxlde som om kulturen har haft travlt med at hente materiale til sine metaforer i den mandlige anatomi. I det ene tilfælde privilegerer man anatomien ved at mene, at den i sidste ende er alle metaforers sagled; i det andet tilfælde privilegerer man den ved at mene, at den er et privilegeret metaformateriale eller billedlager.

Fra et kritisk, feministisk perspektiv må man efterlyse et supplement til "fallos", til de kulturbærende metaforer og begreber der er støbt over den mandlige anatomi. Man må efterlyse metaforer, der er støbt over den kvindelige anatomi. Det man savner, er på den ene side nogle metaforer for kvindekroppen, på den anden side at kvindekroppen bliver gjort til metafor.

På sin vis er det fuldstændig fejlagtigt at hævde, at vi mangler metaforer for kvindekroppen. I den litterære metafortradition kan det synes som om metaforens ypperste bestræbelse er at give et billede af kvindekroppen (den altid undvigende). Ganske som malerne gennem kunsthistorien bestandig har malet billeder af kvindekroppen, bestandig har varieret og raffineret og minimeret deres palet og strøg og konturer for at indfange den æggende, fascinerende, uindfangelige kvindekrops farver og former og kurver og konsistens - således har også poeterne forsøgt at indfange kvindekroppen i bestandig nye billeder. Det er ikke tilfældigt, at det eksempel der altid bliver brugt i pædagogiske tekster til at forklare hvad en metafor er, er "rose" som metafor for "kvinde". Men dette bestandige fors $\varnothing \mathrm{g}$ på at billedliggøre kvindekroppen, som er et fundamentalt projekt i den patriarkalske kultur, indebærer åbenlyst en objektgørelse af kvindekroppen. Her produceres ikke metaforer for den kvindelige anatomi, men for mandens fantasier om den kvindelige ana- tomi. Man kan endog hævde, at i dette projekt gøres hele kvindekroppen til en fallos, til en fuldendt form. Skal man tænke sig nogle anatomiske metaforer, der virkelig supplerer patriarkatets (fallos), må man tænke sig nogle metaforer, der er støbt over den kvindelige anatomi, som den opleves fra kvindens eget perspektiv.

Der findes psykoanalytiske teoretikere, der har forsøgt at udkaste sådanne supplerende metaforer til fallos. Melanie Klein har gjort brystet til en fundamental anatomisk metafor, og Luce Irigaray har forsøgt at sætte kønslæberne i omløb som metafor. Didier Anzieu har udkastet "huden" som en alternativ anatomisk metafor, og det virker jo umiddelbart ikke særlig kønsspecifikt, men jeg skal forsøge at vise, hvordan det er muligt at tænke kønnet på en ny måde, hvis man tænker det i hudens billede.

\section{BRYSTET}

Hos Freud (og senere Lacan) er fallos det forskelsstiftende princip, der gør os til talende og begærende væsener. "Fallos" indstifter forskellen mellem reelt organ (penis) og symbol (fallos). I Ødipusteorien indstiftes "fallos" af kastrationen og fadernavnet: kastrationen er netop det snit, der skiller det symbolske og imaginære fra det reelle (fallos fra penis); fadernavnet er den lov (incesttabuet), der sætter skel mellem moderen og barnet, og som også selv indebærer et skel mellem symbolsk (den abstrakte faderautoritet) og reelt (den konkrete far). "Fallos" er emblemet for hele sprogets og begærets logik, som bygger på kastrationen (det vil sige ufuldkommenheden: umuligheden af den permanente og fuldkomne sammensmeltning, mellem mor og barn, mellem mand og kvinde, mellem tegn og betegnet, mellem symbolet og det reelle).

Afgørende for, at subjektet bliver et subjekt, er, at der sættes skel. Der må sættes skel mellem moderens og barnets krop. Det er i den freudiansk-lacanianske teori, det der sker gennem faderautoriteten: det fa- 
dernavn (nom du père) som også er faderens nej (non du père) til den intime kontakt mellem mor og barn, det vil sige (faderens) kastration (af sønnen). Den faderlov, hvis primære forbud er incesttabuet, som ikke bare indstifter et skel mellem mor og barn, men også mellem "godt" og “ondt". Emblemet for denne skel-sxttende lov er fallos: fallos som er potensens (faderautoritetens) symbol, men som netop er et symbol og må skelnes fra den reelle (ikke permanent potente) penis.

Den skelsættende begivenhed der skaber subjektet og som sit emblem har "fallos", er den begivenhed, der i Det Gamle Testamente skildres som Syndefaldet. Syndefaldet er netop, at skellet og forskellen indtræffer. Skellet mellem godt og ondt ("I bliver som Gud til at kende godt og ondt"), forskellen mellem mand og kvinde (som făr dem til at skjule deres køn bag figenblade). Adam og Eva kastes ud i den ufuldkomne ("kastrerede") tilstand, som gør dem til begærende kønsvæsener - og til potentielle etiske væsener der kan skelne mellem godt og ondt. Også syndefaldets skelsxtten har sin emblematiske fallos: slangen. Men hvad sker der, hvis vi tænker os "fallos" ikke i slangens, men snarere i æblets billede? Hvad sker der, hvis vi tænker os det symbol, der indstifter skellet og forskellen ikke i billedet af penis, men i billedet af moderbrystet? Hvad sker der, hvis den fuldendte form ikke længere stiliseres i den falliske søjle men i brystets kuppel?

Melanie Klein udbygger Freuds teorier i to retninger: dels placerer hun de afgørende psykiske formationer på et tidligere barndomsstadie, nemlig hos det helt spæde barn, dels supplerer hun Freuds teori om drengens kastrationsangst med en teori om pigens angst for at blive tømt for sine indre organer. Disse udbygninger indebærer begge, at den mandlige anatomi suppleres med den kvindelige: kastrationsangsten får sin kvindelige pendant, og (fantasierne om) brystet bliver lige så afgørende for psykens dannelse som (fantasierne om) penis.
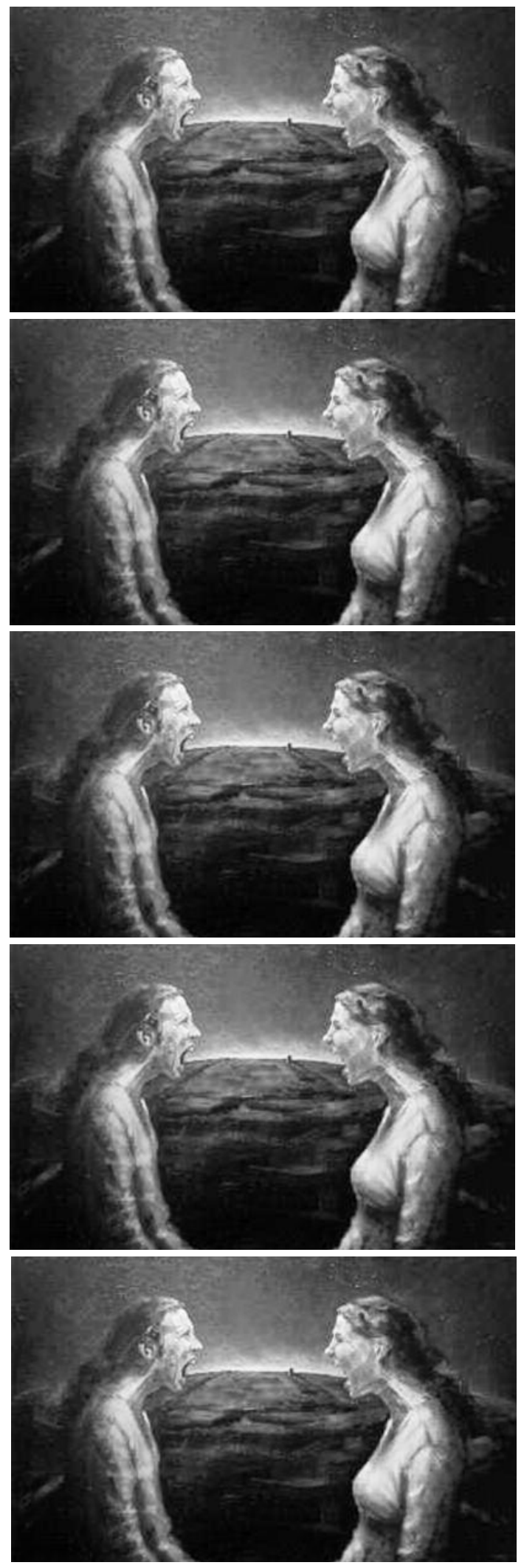
I teorien om pigebarnets angst for at blive tømt, ligger en erkendelse af, at pigens "dyrebare objekt" ikke (som penis) er et ydre, synligt attribut til hendes krop, men et indre organ. Hvilket igen, i erkendelsen af anatomiens metaforiske karakter, ikke bare kan forstås som en reel kropserfaring, men også som den metafor den kvindelige anatomi tilbyder hende at forstå sig selv i. I teorien om brystet ligger derimod en erkendelse af, at moderbrystet er den første "fallos", der melder sig for barnet: det første tegn på potens som barnet er underkastet. Hvis "fallos" som forskelsstiftende princip erstattes af "brystet", så sker der det, at den forskel der gør os til talende og begærende væsener, allerede indfinder sig i barnets forhold til moderbrystet. Så er det ikke længere bare den faderlige (kastrerende) position, der indstifter forskellen, men også den moderlige. Så kan vi tænke os en moderlig position, der ikke bare er den kannibalistisk opslugende som man må værge sig mod med fallos, men som også sætter de skel, der er forudsætningen for sprog og etik.

I Kleins teori er moderbrystet for det lille barn splittet i to: det gode bryst og det onde bryst. Det gode bryst er det nærværende og næringsgivende bryst; det onde bryst er det almægtige og så at sige tyranniske bryst, der kommer og går som det passer det; hvis nærvær barnet ikke kan kontrollere. Juliet Flower MacCannell hævder, at Melanie Klein med moderbrystet funderer en etik i (relationen til) moderen; en etik der ikke (som eksempelvis Julia Kristevas idyllisering af mor-barn-dyaden) er sentimental, men medtænker "det onde bryst": det aspekt ved moderen der af barnet opleves som skræmmende almagt (MacCannell 2000, 168-172). Ifølge MacCannel er Kleins skel mellem det onde og det gode bryst et alternativ til den falliske skelsætten, til fallos som skelsætter. Det er via brystet, at barnet begynder at sætte de skel, som er forudsætningen for at blive et (begærende, talende og måske etisk) subjekt.
Med Kleins bryst får kvinden (moderen) et delobjekt der er analogt med mandens penis. Den moderlige anatomi bliver materiale for en metaforik (det onde og det gode bryst), der indfører nogle fundamentale symbolske skel i barnets psyke, inden fallos og kastrationen (i den mandlige anatomis billede) sætter sit skarpe skel mellem mor og barn og mellem tegn og betegnet.

I sit skift fra "fallos" til "bryst" (eller til brystet som fallos), varierer MacCannell den lacanianske defintion af den kvindelige position som "ikke helt fallisk" med definitionen "ikke helt bryst". Det vil sige at kvinden ikke defineres i forhold til det delobjekt, der er støbt over den mandlige anatomi (fallos), men i forhold til det delobjekt der er støbt over den kvindelige anatomi, og at hun her defineres som én der ikke går restløst op i sit delobjekt. At kvinden ikke går restløst op i moderbrystet, betyder så meget som, at hun ikke kun er den moderlige potens, som brystet er den anatomiske metafor for. Hun er også "den skrøbelige anden, den anden som mangler og begxrer" (MacCannell 2000, 170).

På sin vis kan man sige, at ved at se fallos i brystets billede, giver MacCannell kvinden en mulighed for at blive kastreret. At kvinden ikke har fallos, som tilfældet er under patriarkatet, betyder også, at hun ikke har kastrationen. Fallos betyder kastration, fordi "fallos" implicerer det snit mellem symbolsk og reelt organ (mellem fallos og penis), som er kastrationen. I den patriarkalske orden er kvindens problem, at hun ikke kan kastreres; at hun ikke kan ses som det "manglende og begærende" (dvs. kastrerede) subjekt for den symbolske orden; hun kan ikke udsættes for det symbolske snit der initierer hende som subjekt i et sprog og et samfund.

Man kan tænke sig drengebarnets omskæring og det dertil hørende ritual som en kropslig konkretisering af den initierende kastration. I de kulturer hvor også pigerne omskæres, viser det sig rent anatomisk, hvordan kvinden ikke kan kastreres. Snittet 
i penis giver på sin vis drengen en fallos: et mere skulpturelt organ der ikke længere kan krybe sammen i forhudens diffuse folder; snittet i klitoris eller kønslæber giver ikke kvinden andet end smerte; giver ingen skulpturel form til kvindens kønsorgan.

Den skulpturelle, "falliske" form hos kvinden finder man snarere $\mathrm{i}$ brystets afrundede kuppel. Her er et ydre attribut, der symboliserer moderlig potens. "Den falliske mor", altså den mor der af barnet opleves som (overvældende) potent, kan vi med Melanie Klein forstå i det almægtige brysts billede. Idet hendes potens lokaliseres i en metafor, der er støbt over hendes reelle anatomi (og ikke i den imaginære penis som Freud udstyrede den falliske mor med), får hun så at sige "sin egen" metafor for fallos, "sit eget" partielle objekt, og dermed også muligheden for (symbolsk) at miste dette objekt, at blive "kastreret" på sin "egen" måde.

Når Lacan definerer kvinden som "ikke helt fallisk", definerer han hende som "ikke helt" underkastet den falliske orden, det vil sige "ikke helt" kastreret. Når MacCannell definerer hende som "ikke helt bryst", definerer hun hende omvendt som kastreret; med denne definition opstår muligheden for at tænke sig en "kastration", det vil sige en initiering til subjekt, også i den kvindelige anatomis billede.

I den freudianske-lacanianske etik er det faderen, der gør barnet til etisk subjekt. Det er faderautoritetens formaninger, der lærer barnet at skelne mellem godt og ondt, mellem rigtigt og forkert. Så længe barnet er tæet forenet med moderen, er det intet etisk væsen; det bliver det først, når faderloven (incesttabuet) skiller mor og barn ad. Faderautoriteten er overjegets oprindelse; overjeget er en internalisering af faderautoriteten. Den moderlige position er derimod fundamentalt uetisk: hvis faderen er roden til overjeget, så er moderen til gengæld roden til det såkaldt obskøne overjeg. Det obskøne overjeg er overjegets ekko; den instans der hvisker: "gør det bare alligevel", hver gang overjeget har dikteret si- ne forbud. Det er den moderlige stemme (som godt kan sidde i struben på en reel far), der siger: "du må egentlig ikke få mere slik, men tag nu bare én til".

Med moderbrystet får vi en supplerende metafor for fallos, eller en fallos i den kvindelige anatomis billede. Med moderbrystet får vi et billede hentet fra den kvindelige anatomi som en fundamental metafor i subjektets dannelse. Men det er ikke en metafor hentet fra den kvindelige anatomi, som den opleves "indefra", af kvinden selv. Med Kleins kvindelige alternativ til kastrationsangsten, angsten for at blive tømt, făr vi derimod en anatomisk metaforik funderet i kvindens egen oplevelse af sin anatomi. I første tilfælde brystet (som ikke findes hos den lille pige), i andet tilfælde livmoderen (som ikke er synlig). Men hvad med det kønsspecifikke organ som er ydre, synligt, og som allerede findes hos den lille pige? Hvad med vagina, hvad med kønslæberne?

\section{LÆBERNE}

Den franske kønsfilosof Luce Irigaray har i en berømt og berygtet tekst forsøgt at sætte kønslæberne i omløb som metafor. "Når vores læber taler med hinanden" hedder teksten og skaber hermed en dobbelteksponeret metafor, hvor billedet af mundens og kønnets læber lægger sig oven i hinanden. Irigarays projekt kan langt hen ad vejen netop beskrives som et forsøg på at sætte nye anatomiske metaforer i omløb. Metaforer for kønnet og ikke mindst relationen mellem kønnene. Frem af vor kulturs filosofiske grundtekster graver Irigaray en række metaforer, som er støbt over en mandlig anatomi - og fremskriver nogle nye, som er støbt over den kvindelige anatomi. Disse nye anatomiske metaforer er ikke bare metaforer for et kvindeligt subjekt, men også for relationen mellem mand og kvinde. For det er måske det, der er Irigarays primære xrinde: at finde nye metaforer, figurer, begreber, diagrammer, formler for relationen mellem kønnene. Metaforer der ikke defi- 
nerer forholdet mellem mand og kvinde som magtkamp, kløft, opslugning eller annektering men snarere som berøring, dia$\log$, skabelse. Og sådanne metaforer forsøger hun at skabe ved at hente materialet til dem i den kvindelige anatomi. Således de talende læbers metafor. Den er på den ene side et billede for det kvindelige subjekt (eller en metafor for subjektet støbt over den kvindelige anatomi), på den anden side et billede på en relation mellem to. De to læber kan både forstås intrasubjektivt (som dele af samme subjekt) og intersubjektivt (som to subjekter).

Med læbernes billede forsøger Irigaray at supplere den falliske logik med noget, man kunne kalde labial logik. I den falliske logik er sproget baseret på kastration og separation: sproget opstår når barnet "kastreres", det vil sige, når det separeres fra moderkroppen af Faderautoriteten. I den falliske logik fordrer sproget en distancering fra moder-/kvindekroppen, som (sprogteoretisk) også bliver en distance mellem ordet og det det betegner, mellem sprog og verden. Irigaray udkaster en metafor, hvor det ikke er adskillelsen ("kastrationen"), men læbernes flygtige møde der producerer sprog. En forestilling om ikke kun at kunne tænke med pikken, men også med kussen. Hermed får vi et subjekt, hvis tale udspringer af kroppen (læberne) frem for af en distance til (kvinde)kroppen.

Lacan definerer subjektet som det splittede (kastrerede) subjekt. I læbernes billede er også Irigarays talende subjekt splittet i to. Men splittelsen er ikke absolut: berøringens mulighed er der hele tiden og realiseres flygtigt. Irigarays læbemetafor "heler" ikke subjektet; det er stadig splittet, men splittelsen er ingen absolut kløft.

Som metafor for relationen mellem to er Irigarays læber blevet læst som en lesbisk metafor: et møde mellem to væsener med kønslæber. Det er utvivlsomt en mulig tolkning, ikke mindst fordi det er Irigarays erklærede ambition at skabe symboler for relationer mellem kvinder; symboler hun savner i den patriarkalske kultur, hvor de symbolske (symboliserede og symbolproducerende) relationer er dem mellem far og søn og mellem brødre. Imidlertid er det væsentlige ved læbemetaforen ikke, hvilke konkrete parter man indsætter på "læbernes" plads (to kvinder, mand og kvinde, to dele af samme subjekt), men hvordan læbemetaforen definerer selve relationen mellem disse. Læberne er i teksten et "vi", et "du" og et "jeg", og metaforen forsøger at tegne et forhold mellem "mig" og "dig", som hverken er enhed eller separation. (Det er dog et problem ved Irigarays tekst, at denne dikotomikritik modsiges af et fast håndhævet skel mellem “dem" og “os". Dette kan siges at være et generelt problem ved Irigarays tidlige tekster: at deres dekonstruktion af dikotomien jeg/du står i modsætning til en dikotomisk kampretorik: dem/os.) Således er læbernes møde et billede på et møde, hvor man ikke annekterer eller opsluger eller smelter sammen med den anden, hvad enten dette møde er hetero- eller homoseksuelt (eller et møde mellem forskellige dele af samme jeg). Med sin læbemetafor fors $\emptyset$ ger Irigaray at udkaste et alternativ til den falliske logik ved at hente materialet til metaforen i den kvindelige anatomi. Denne alternative metafor ekskluderer ikke manden, men gør det muligt for ham og kvinden at møde hinanden (og sig selv) på en måde, der er alternativ til den patriarkalske model.

Det er vigtigt at forstå den anatomiske metafors status hos Irigaray: at den ikke er et forsøg på at føre alting tilbage til anatomi, men at udvinde nye billeder af anatomien; af den kvindelige anatomi udvinde billeder der kan supplere de mandligt anatomiske billeder, der har skjult sig i de begreber som strukturerer vores selv- og verdensoplevelse. Irigarays krop har altså ikke status af biologisk essens, men snarere af metaformateriale.

Irigarays kropslige billeder, som har provokeret mange, er et forsøg på at sætte nye metaforer i omløb, ikke at referere til en krop der skulle findes inde "bag" alle meta- 
forerne. Michelle Boulouse Walker har forsøgt at forklare Irigarays ikke-essentialisme på følgende måde: "biology (or nature) must receive a symbolic mediation which is more adequate for women" (Walker 1998, 173). Ifølge Walker er Irigarays projekt altså ikke at føre os tilbage til en biologi hinsides al symbolisering, men tværtimod at skabe nye symboler, der så, som det hedder, skal være "mere adækvate for kvinder". Hertil må man tilføje, at symboler hentet fra den kvindelige anatomi også kan være mere adækvate for mænd eller for relationen mellem mænd og kvinder.

Forskydningen fra Kleins bryst til Irigarays vagina er en forskydning fra mor til kvinde. Irigaray gør bestandig opmærksom på, at vi må finde nogle figurer, hvori vi kan opfatte kvinden som noget andet end mor; at en af de patriarkalske definitioner af kvinden er identifikationen af "kvinde" og "mor", af "kvindelighed" og "moderlighed”. Så længe metaforerne for kvinden er moderbryst og livmoder, forbliver kvinden i moderens billede. Med læberne forskydes metaforen til noget kvindeligt, der ikke har nogen moderlig funktion, men måske kan blive emblem for kvinden hinsides moderligheden (kvinden som begærende, manglende subjekt, som MacCannell ville sige "ikke helt bryst").

En anden anatomisk metafor for det kvindelige begær, som noget andet end moderligt, er selve flerheden af erogene zoner. Det er denne flerhed Irigaray henviser til med titlen på en af sine bøger: Ce sexe qui n'en est pas un: "Dette køn som ikke er et". Titlen rummer selv en flerhed af betydninger: "Dette køn" som ikke findes i den eksisterende patriarkalske orden (kvindekønnet); “dette køn” som er druknet i universalitet og neutralitet (mandekønnet); “dette køn" som altid er to (kønnet er altid et ud af to; der findes intet køn, før der findes to køn); “dette køn” (kvindekønnet) der ikke (som penis) er koncentreret i ét kønsorgan, men spredt ud i en flerhed af erogene punkter, flader og åbninger.
I forholdet mellem de to læber er relationen defineret af berøring. Relationen er en hud-relation. Mellem de to er der ingen fallisk koblestang eller et fallisk sværd, men en grænse som er hudens og et medium som er flydende: slim, spyt, sekret. Det forskelsstiftende princip mellem de to er ikke længere brystets æblekuppel eller slangens falliske form, men snarere slangens skin, slangens ham, slangens hud. Jeg skal afslutningsvis forsøge at introducere huden som et tredje bud på en anatomisk metafor, der kunne være et alternativ eller supplement til fallos.

\section{HUD}

Under patriarkatet er fallos det forskelsstiftende princip. Fallos definerer relationen mellem (de) to (køn) og definerer samtidig enhver relation mellem to som en kløft, en uovervindelig afstand, en absolut adskillelse der kun fantasmatisk kan overvindes af den falliske koblestang. Hvis fallos er det forskelsstiftende princip, er forskellen mellem kønnene defineret som en haven eller ikkehaven fallos (kvinden som kastreret); en haven eller væren fallos (kvinden som objekt); en væren fallisk eller ikke-helt fallisk (kvinden som mystisk).

Hvis man i stedet tænker sig det forskelsstiftende princip i hudens billede; hvis man forsøger at supplere "fallos" med den anatomiske metafor "hud", får man et andet billede for selve forskellen. Så er forskellen en grænse, der på én gang adskiller og forener. Huden adskiller mig fra den anden, sætter en grænse mellem os, men denne hudgrænse er samtidig berøringens sted; forudsætningen for at vi overhovedet kan røre ved hinanden. I hudens billede hersker der altid denne dialektik mellem afgrænsning og berøring. Grænsen eller adskillelsen bliver ingen uovervindelig kløft men forudsætningen for udveksling.

Huden er en anatomisk metafor, man glimtvis kan finde hos Luce Irigaray. "Vi har glemt vores hud", skriver hun i Dette 
kon som ikke er et, og i Konsforskellens etik efterlyser hun en hud til kvinden: "For at kunne være et hylster, må hun have sit eget hylster. Ikke kun sit tøj eller sin forførende pynt, men sin hud." (Irigaray 1984, 42)

At være og have et hylster bliver her Irigarays definition på at være et subjekt (i modsætning til den objektposition som er kvindens under patriarkatet). I hylsterets billede bliver subjektet den, der kan rumme sig selv, den, der kan bo i sig selv, den, der har hjemme i sig selv. Vel at mærke ikke den der forskanser sig i sig selv; som Irigaray påpeger, er et hjem defineret ved at man kan gå ind og ud af det (Irigaray 1984, 68). Huden bliver det anatomiske billede på dette hylster. Har man hjemme i sin hud, kan man meget vel "gå ud af sit gode skin". Huden er ikke et hårdt panser man forskanser sig bag, men en porøs, gennemtrængelig og hypersensibel flade, som på én gang er stedet for afskærmning og intim kontakt. I hudens billede bliver subjektets hylster (eller subjektet-som-hylster) ingen skarpt optrukken front mod omverden, men en på én gang følsom, modtagelig og værnende flade.

I patriarkatets konventionelle anatomiske metaforik er kvinden (vagina eller livmoder) hylsteret for manden (penis eller drengefoster). Den anatomiske figur har sin sociale analogi i patriarkatets konventionelle kønsroller: kvinden skaber et hjem som manden kan komme hjem og hvile ud i. Det er Irigarays pointe, at i denne falliske metaforik har hverken mand eller kvinde sit eget hylster; ingen af dem har hjemme i sig selv. Manden har sit hjem i kvinden, ikke i sig selv; kvinden har ikke noget hjem, fordi hun er hjemmet. Og så længe kvinden ikke er et hjem for sig selv, kan hun i virkeligheden heller ikke være det for manden. Forudsætningen for, at kvinden får et hylster eller en hud, er således, at manden får en hud og ikke er henvist til at finde den $\mathrm{i}$ kvinden. Det er ikke bare kvinden, der savner hud under patriarkatet, det er også manden. Den patriarkalske mand er en mand forskanset bag pansre, bag falliske substituthuder: Herkules' løveskind, ridderens rustning, kaptajnens våbenfrakke. Den patriarkalske mand er, som både August Strindberg og Klaus Theweleit belærer os om, den ikke færdig-fødte mand, og det betyder også den mand, som aldrig har fået sin egen hud.

Huden kan virke som et kønsløst billede. Altså et billede der ikke kan leve op til det krav om den kønsspecifikke anatomi, som jeg i artiklens start opstillede i polemik mod kropsfænomenologien og den kognitive semantik. Men snarere end at afskedige kønsorganerne som vigtige anatomiske metaforer, giver huden os et andet billede af kønsorganerne end den stav og det hul som penis og vagina er blevet til under patriarkatet. Hvis penis betragtes i hudens billede, og ikke i billedet af fallos, bliver penis noget andet end en stav, en monumental og frem-ragende form. Så defineres penis ikke hele tiden ud fra sin potentielle erektion men ud fra sin potentielle hvilen i forhudens lomme. Så behøver penis ikke at være erigeret for, at manden er "nogen" (for at manden har et hjem; for at han kan finde hjem i kvinde); så er manden også "nogen" (har et hjem) i sig selv. Hvis vagina betragtes i hudens billede, og ikke fra det falliske perspektiv, bliver vagina noget andet end et hul. Så er vagina ikke den gabende kløft, den mørke afgrund, det "intet", den kannibalistiske slugt den er blevet i den patriarkalske fantasi. Så er vagina et rum, et hylster, en formation af hudfolder. Et rum der kan føle og mærke; hud der kan mærke sig selv (de to læber). Så er kvinden ikke bare hylster for manden, men har også sit eget hylster i sig selv. Og endelig: hvis samlejet betragtes i hudens billede, bliver det ikke et billede af en stav eller pil der peger ind i et hul, men af hud der gnider sig mod hud: krop mod krop, læber mod læber, glans mod slimhinder.

Brystet, læberne, flerheden af erogene zoner, huden - disse anatomiske metaforer er 
hentet fra (eller inkluderer) den kvindelige anatomi og er dermed alternativer eller supplementer til vor kulturs anatomiske metafor par excellence, fallos. Hvis "brystet" forbliver inden for den falliske logik (brystet er, som fuldendt form og fantasmatisk objekt, en fallos), så giver læberne, flerheden og huden os til gengæld nogle billeder hinsides den falliske logik; nogle billeder hvori forskellen sættes af en grænse som ikke er en mur eller kløft, men en berøringsflade og hvor kønsforskellen ikke er et spørgmål om at have eller ikke have fallos, men om at på én gang afgrænse og møde sig selv og hinanden hud mod hud. Så bliver slangen mellem Adam og Eva til selve den kontur der tegner deres forskellige silhouetter.

\section{LITTERATUR}

. Irigaray, Luce (1977): "Quand nos levres se parlent", Ce sexe qui n'en est pas un, Éditions de Minuit. Paris

- Irigaray, Luce (1984): Ethique de la différence sexuelle, Éditions de Minuit, Paris

- Laplanche, Jean (1970): Vie et mort en psychanalyse, Flammarion, Paris

- MacCannell, Juliet Flower (2000): The Hysteric's Guide to the Future Female Subject. The University of Minnesota Press, Minneapolis - Paglia, Camille (1990): Sexual Personae, Yale University Press, New Haven

- Strindberg, August (1912): Fadren, Samlade Skrifter Bd. 23, Bonniers, Stockholm
- Theweleit (1977-1978): Männerphantasien, Roter Stern, Frankfurt am Main

- Walker, Michelle Boulous (1998): Philosophy and the Maternal Body, Routledge, New York

\section{SUMMARY}

The article tries to define the state of the anatomical metaphor in psychoanalysis, arguing that from a psychoanalytical point of view, everything "means" body and the body always "means" something else than itself. That is, the body is at the same time the "tenor" of every metaphor and material for metaphorical "vehicles". The body is not the answer to all mysteries, but a mystery in itself. The most important metaphor in psychoanalysis, the phallus, is despite of its metaphorical character based on male anatomy, and the article tries to find alternative or supplementary metaphors based on (or including) female anatomy: the breast, the two lips, the multitude of erogenous zones, the skin. It is argued that those metaphors may offer concepts of subjectivity which are not only more appropriate for women, but also for men, and for the definition of the very relation between man and woman.

Lillian Munk Rösing

ph.d., amanuensis ved Litteraturvidenskab, KUA og kritiker ved dagbladet Information 